\title{
Model Pembelajaran STAD Untuk Meningkatkan Motivasi Dan Prestasi Belajar Siswa 8I SMPN 1 Dolopo
}

\section{Endah Murtiningsih ${ }^{*}$}

${ }^{1}$ SMP Negeri 3 Dolopo Kecamatan Dolopo Kabupaten Madiun Provinsi Jawa Timur

*Email: endahmurtiningsihfis@yahoo.com

\section{Info Artikel}

Diterima: 28 Januari 2021
Direvisi: 26 Oktober
Diterima
untuk diterbitkan: 27 Oktober
2021

\begin{abstract}
Abstrak
Kurikulum Tingkat Satuan Pendidikan (KTSP) menuntut peran guru dalam proses pembelajaran agar siswa memiliki pengalaman belajar yang bermakna. Siswa kelas 8I SMPN 1 Dolopo motivasi dan hasil belajar masih rendah, hal ini terbukti dari hasil ulangan siswa yang mendapat nilai di bawah KKM mencapai di bawah 50\%. Guru berupaya meningkatkan motivasi dan hasil belajar siswa dengan menggunakan model pembelajaran STAD (Student Team Achievement Division) dengan tahapan penyajian materi, diskusi kelompok, diskusi kelas, tahap kuis, dan pemberian penghargaan. Subjek penelitian adalah siswa kelas 8I SMPN 1 Dolopo Madiun dengan jumlah siswa 32 siswa, terdiri dari empat belas siswa laki-laki dan delapan belas siswa perempuan. Penelitian terdiri dari 2 siklus, masing-masing mengukur motivasi dan prestasi belajar dengan menggunakan lembar motivasi dan hasil belajar. Berdasarkan tindakan siklus I dan II diperoleh hasil, yaitu motivasi belajar siswa yang terdiri atas: frekuensi pertanyaan yang diajukan siswa, perhatian siswa, kerjasama siswa dalam kelompok, dan peningkatan sumber belajar yang dimanfaatkan siswa pada siklus I mempunyai rata-rata $58,18 \%$ meningkat menjadi $69,59 \%$ dan siklus II untuk motivasi siswa meningkat sebesar $11,41 \%$. Persentase ketuntasan klasikal menunjukkan prestasi belajar siswa meningkat dari $66,67 \%$ di siklus I menjadi $88,89 \%$ di siklus II atau meningkat sebesar $22,22 \%$. Hal ini karena siswa telah mengikuti model pembelajaran STAD dengan skenario: (1) menyajikan materi, (2) diskusi kelompok, (3) diskusi kelas, (4) kuis, dan (5) memberikan penghargaan. Berdasarkan data keterlaksanaan penggunaan model pembelajaran STAD, diketahui bahwa rata-rata mencapai 76,2 dengan nilai terbesar pada menjelaskan tujuan pembelajaran, memberikan kuis, dan memberikan penghargaan. Berdasarkan hasil penelitian tersebut, maka dapat diketahui model pembelajaran STAD dapat meningkatkan
\end{abstract}



semester genap tahun pelajaran 2014/2015. Harapan ke depannya dari hasil penelitian ini, guru diharuskan untuk menggunakan model pembelajaran STAD dalam pembelajaran berikutnya.

(C) 2021 Universitas Bengkulu. This is an open-access article under the CC-BY license (https://creativecommons.org/licenses/by/4.0)

\section{PENDAHULUAN}

Berdasarkan análisis ulangan harian satu tahun yang lalu dapat diketahui, bahwa motivasi dan prestasi belajar siswa kelas 8I masih rendah dengan kriteria ketuntasan minimal (KKM) 65. Hal ini terbukti dari hasil tes ulangan harian, masih banyak siswa yang belum tuntas belajar atau dikatakan bahwa persentase ketuntasan masih rendah. Banyak siswa tidak memperhatikan penjelasan guru, hal ini terlihat di dalam pembelajaran ada yang menggambar, ada yang bercanda dengan teman sebangku sehingga mengganggu proses pembelajaran. Saat disuruh kerja kelompok, yang mau mengerjakan hanya beberapa saja, yang lain hanya ramai saja, bahkan ada yang tidak membawa buku pelajaran. Dari hasil pengamatan terdapat beberapa kekurangan dalam proses pembelajaran, yaitu sebagai berikut: pembelajaran berpusat pada guru, rendahnya motivasi belajar siswa akibat siswa pasif dalam pembelajaran di kelas, siswa kurang berani mengungkapkan ide-ide dalam pikirannya, siswa jarang bertanya kepada guru tentang materi yang belum dipahami, siswa kurang maksimal dalam diskusi kelompok. Dari kekurangan tersebut, Guru ingin mengubah model pembelajarannya dengan menerapkan model pembelajaran STAD dengan tujuan untuk meningkatkan motivasi dan prestasi belajar siswa dalam mengikuti pembelajaran atau proses belajar.

Belajar adalah perubahan tingkah laku yang relatif mantap berkat latihan dan pengalaman yang dilakukan manusia seumur hidup, kapan saja, dimana saja, baik di sekolah maupun di rumah dalam waktu tertentu dilandasi itikad dan maksud tertentu (Hamalik, 2001). Pengetahuan dibentuk oleh individu yang berinteraksi dengan lingkungan, sehingga mengalami perubahan dari tindakan. Perkembangan kognitif bergantung pada keaktifan yang merupakan akumulasi dari kepingan informasi terpisah atau mengkonstruksian siswa untuk memahami lingkungan. Skinner, belajar merupakan hubungan antara stimulus dan respon melalui proses tingkah laku (Dimyati \& Mujiono, 2006). Belajar merupakan proses usaha untuk memperoleh perubahan tingkah laku yang baru secara keseluruhan, sebagai hasil pengalamannya sendiri dalam interaksi dengan lingkungan (Slameto, 2003). Belajar dilakukan dengan sengaja dan direncanakan sebelumnya dengan struktur tertentu agar proses dan hasil belajar dapat terkontrol dengan baik melalui penilaian secara berkesinambungan.

Belajar memerlukan motivasi secara terus-menerus untuk memusatkan pikiran dan perhatian pada materi atau bahan-bahan yang diberikan guru yang berkepribadian dinamis, baik sikap dan minatnya. Motivasi ada dua bentuk, yaitu motivasi intrinsik yang dapat mencapai tujuan belajar siswa untuk menambah wawasan dan pengetahuannya, sedangkan motivasi ekstrinsik siswa belajar bukan untuk menambah wawasan dan pengetahuannya tetapi di luar perbuatan belajar. Tanpa belajar seseorang tidaklah mungkin menjadi ahli dalam bidang tertentu (Wongkeban, 2008).

Motivasi belajar dapat timbul karena faktor intrinsik, berupa hasrat dan keinginan berhasil, dorongan kebutuhan belajar, dan harapan akan cita-cita. Sedangkan faktor ekstrinsiknya adalah adanya penghargaan, lingkungan belajar yang kondusif, dan kegiatan belajar yang menarik. Kedua faktor tersebut disebabkan oleh rangsangan tertentu, sehingga seseorang berkeinginan untuk melakukan aktifitas belajar yang lebih giat dan semangat. Perubahan tingkah laku meliputi: (1) adanya hasrat dan keinginan berhasil; (2) adanya dorongan dan kebutuhan dalam belajar, (3) adanya harapan dan cita-cata masa depan, (4) adanya penghargaan dalam belajar; (5) adanya kegiatan yang menarik dalam belajar, (6) adanya lingkungan belajar yang kondusif sehingga memungkinkan siswa dapat belajar dengan baik (Hamzah, 2008). Siswa yang termotivasi belajar dapat terlihat dari tingkah laku dan keaktifan siswa dalam proses belajar mengajar sesuai dengan pernyataan dari 
Anderson dan Faust dalam Ellyana (2007) yang menyatakan motivasi belajar dapat terlihat dari karakteristik tingkah laku siswa yang menyangkut minat, ketajaman perhatian, konsentrasi, dan ketekunan. Siswa yang memiliki motivasi yang tinggi dalam belajar menampakkan minat yang besar dan perhatian yang penuh terhadap tugas-tugas belajar. Mereka memusatkan sebanyak mungkin energi dan fisik maupun psikis terhadap kegiatan tanpa mengenal perasaan bosan, apalagi menyerah. Hal sebaliknya terjadi pada siswa yang memiliki motivasi rendah. Mereka menampakkan keengganan, cepat bosan, dan berusaha menghindar kegiatan belajar.

Siswa yang memiliki motivasi tinggi maupun rendah terlihat jelas saat mengikuti pembelajaran. Siswa yang mempunyai motivasi tinggi, maka terlihat aktif dalam berdiskusi, menjawab pertanyaan guru, dan sebagainya, namun siswa yang memiliki motivasi rendah, maka dalam mengikuti pembelajaran akan malas-malasan, tidak mendengarkan penjelasan guru, tidak mau menjawab bila ditanya dan sebagainya. Menurut Suciati (2006) ada empat hal yang menunjukkan siswa termotivasi dalam belajar yaitu: 1) perhatian, 2) relevansi, 3) percaya diri, 4) kepuasan. Adapun dalam penelitian ini untuk mengukur motivasi siswa yang diamati terdiri atas empat aspek, yaitu (1) frekuensi pertanyaan yang diajukan siswa, (2) perhatian, (3) kerjasama antar siswa dalam menyelesaikan tugas, (4) peningkatan sumber belajar yang dimanfaatkan oleh siswa (Soeharto, 2003).

Prestasi belajar merupakan suatu puncak proses belajar yang dipengaruhi oleh proses-proses penerimaan, keaktifan, pra pengolahan, pengolahan, penyimpanan, serta pemanggilan untuk pembangkit pesan dan pengalaman (Dimyati \& Mudjiono, 2006). Prestasi belajar dapat dipandang sebagai suatu kemampuan yang dimiliki oleh siswa, sehingga dapat diukur dan hasil pengukurannya berupa skor atau angka yang merupakan gambaran dari hasil proses pembelajaran. Perubahan tingkah laku yang diharapkan dalam penerapan model pembelajaran STAD ini berasal dari interaksi sosial, dimana siswa saling bertanggung jawab terhadap diri sendiri dan anggota kelompoknya, sehingga dihasilkan suatu keadaan dimana siswa yang awalnya tidak tahu akan menjadi mengerti. Ridwan (2007) mengemukakan bahwa prestasi belajar dipengaruhi oleh faktor-faktor intern berupa kecerdasan, bakat, minat dan motivasi, sedangkan faktor ekstern meliputi bahan pelajaran, metode mengajar, media pendidikan, dan situasi lingkungan. Kedua faktor tersebut memiliki peranan penting di dalam mempengaruhi prestasi belajar siswa. Tinggi rendahnya prestasi belajar siswa dapat diketahui setelah diadakan evaluasi. Model pembelajaran Student Team Achievement Divisio (STAD) termasuk model pembelajaran kooperatif. Semua model pembelajaran kooperatif ditandai dengan adanya struktur tugas, struktur tujuan, dan struktur penghargaan. Dalam proses pembelajaran dengan model pembelajaran kooperatif, siswa didorong untuk bekerjasama, koordinasi dalam menyelesaikan tugas dari guru dengan tujuan siswa dapat menerima berbagai keragaman dari temannya, serta pengembangan keterampilan sosial. Adapun enam langkah model pembelajaran STAD meliputi: 1) menyampaikan tujuan dan memotivasi siswa, 2) menyajikan informasi, 3) mengorganisasikan siswa dalam kelompok belajar, 4) membimbing kelompok belajar, 5) evaluasi, dan 6) memberikan penghargaan. Model pembelajaran STAD dikembangkan oleh Robert Slavin dan teman-temannya di Universitas John Hopkins. Siswa dalam suatu kelas tertentu dipecah menjadi kelompok dengan anggota empat sampai lima orang heterogen, terdiri laki-laki dan perempuan, berasal dari berbagai suku, memiliki kemampuan tinggi, sedang, dan rendah. Anggota tim menggunakan lembar kegiatan atau perangkat pembelajaran yang lain untuk menuntaskan materi pelajarannya dan kemudian saling membantu satu sama lain untuk memahami bahan pelajaran melalui diskusi dan kuis. Aufa dan Haq (2020) menyatakan bahwa penggunaan model STAD dapat meningkatkan prestasi belajar siswa.

Pengajaran IPA yang disajikan dengan model pembelajaran STAD memungkinkan untuk memberikan pengalaman-pengalaman sosial siswa, sebab mereka akan bertanggung jawab pada diri sendiri dan anggota kelompoknya. Keberhasilan anggota kelompok merupakan tugas bersama. Dalam pembelajaran STAD ini, anggota kelompok berasal dari tingkat prestasi yang berbeda-beda, sehingga melatih siswa untuk bertoleransi atas perbedaan dan kesadaran akan perbedaan, melatih siswa untuk menceriterakan, menulis secara benar apa yang diteliti dan diamati, sehingga dapat 
meningkatkan motivasi dan prestasi belajar siswa. Penggunaan model pembelajaran STAD telah terbukti dapat meningkatkan prestasi dan hasil belajar peserta didik (Sumarni \& Mansurdin, 2020: Hirmanudin, 2015)

\section{METODE}

Penelitian Tindakan Kelas (PTK) yang didesain ini merupakan penelitian kuantitatif yang mengacu pada model Kemmis dan M.C Taggart dalam Susilo (2008) yang terdiri dari empat komponen, yaitu: perencanaan tindakan, pelaksanaan tindakan, observasi, dan refleksi.

Berdasarkan pendekatan dan jenis penelitian, maka kehadiran peneliti di lapangan sangat diperlukan, karena peneliti bertindak sebagai pengelola instrumen, perancang tindakan, pelaksana tindakan dan pelapor hasil penelitian. Selama pelaksanaan tindakan dibantu tiga orang observer dengan maksud untuk membantu peneliti dalam pengumpulan data melalui observasi motivasi siswa di dalam kelas.

Subjek penelitian adalah siswa kelas 8 I SMPN 1 Dolopo Madiun dengan jumlah siswa tiga puluh dua siswa, terdiri dari empat belas siswa laki-laki dan delapan belas siswa perempuan. Kelas ini dipilih karena ketuntasan belajarnya sangat rendah bila dibanding dengan kelas lain.

Data yang akan dikumpulkan meliputi: data motivasi yang bersumber dari siswa dan data prestasi belajar yang bersumber dari hasil tes siswa. Instrumen yang digunakan dalam penelitian ini adalah: 1) instrumen yang dipakai untuk mengukur motivasi siswa adalah lembar observasi motivasi. Motivasi yang diukur terdiri dari: (1) frekuensi pertanyaan yang diajukan siswa, (2) perhatian, (3) kerjasama antar siswa dalam menyelesaikan tugas, (4) peningkatan sumber belajar yang dimanfaatkan oleh siswa (diadaptasi dari Soeharto, 2003). Adaptasi ini dilakukan sesuai dengan kajian pustaka dan kebutuhan data yang peneliti harapkan, 2) instrumen yang dipakai untuk mengukur prestasi siswa adalah soal post test siklus I dan siklus II. Bentuk tes pilihan ganda sebanyak 40 soal. Sebelum soal ini digunakan kepada siswa, terlebih dahulu dikonsultasikan kelayakannya kepada guru mata pelajaran IPA yang lainnya, observer, dan pembimbing yaitu kepala sekolah sebagai ahli.

\section{Teknik Pengumpulan Data}

\section{Observasi Motivasi}

Pengumpulan data motivasi siswa adalah dengan observasi langsung. Sebelum melakukan kegiatan observasi, peneliti dan tiga orang observer melakukan diskusi untuk menyamakan persepsi menentukan skor motivasi siswa. Masing-masing observer mengamati tiga sampai empat kelompok. Observer mengamati aspek-aspek yang tertera pada lembar observasi motivasi sehingga dapat mengamati perubahan motivasi belajar siswa secara langsung. Aspek-apek motivasi siswa yang diamati adalah frekuensi pertanyaan yang diajukan siswa, perhatian siswa, kerjasama siswa dalam menyelesaikan tugas kelompok, dan peningkatan sumber belajar yang dimanfaatkan siswa.

Observasi Prestasi Belajar

Pretest dalam penelitian ini dilakukan secara lisan saja hanya untuk mengetahui pemahaman atau pengetahuan awal siswa, sehingga tidak digunakan untuk mengukur prestasi belajar siswa. Sedangkan post test yang diberikan berupa tes tertulis sehingga hasilnya digunakan untuk mengukur hasil prestasi belajar. Test atau soal yang diberikan kepada siswa dalam bentuk bahasa tulisan. Pelaksanaan post test dilakukan pada akhir siklus. Materi post test siklus I yaitu cermin dan materi post test siklus II yaitu lensa. Waktu pelaksanaan post test selama tiga puluh menit.

\section{Analisis Data}

Pengambilan data dilakukan selama proses penelitian, sementara analisis data dilakukan setelah meninggalkan tempat penelitian (Moleong, 2005). Data yang dianalisis dalam penelitian ini adalah:

\section{Analisis Data Lembar Observasi Motivasi Siswa}

Analisis data hasil observasi motivasi siswa digunakan untuk menjawab permasalahan tentang rendahnya motivasi siswa di dalam pembelajaran. Persentase keberhasilan motivasi dihitung dengan menggunakan rumus sebagai berikut: 
Persentase Rata-rata Motivasi $=\frac{\text { jumlah skor yang dicapai }}{\text { jumlah skor maksimum }} \times 100 \%$

(Soeharto, 2003)

Analisis Data Prestasi Belajar

Prestasi belajar siswa ditentukan berdasarkan ketuntasan belajar siswa dengan patokan ketercapaian nilai KKM, yaitu nilai 70. Skor yang diperoleh siswa melalui post test pada tiap siklus akan digunakan untuk menentukan ketuntasan individual dan ketuntasan klasikal terhadap indikator yang telah ditetapkan. Ketuntasan individual atau ketuntasan per siswa ditentukan dengan rumus:

$\mathrm{K}=\frac{\text { jumlah } \text { skor yang dicapai }}{\text { jumlah skor maksimum }} \quad \mathrm{x} 100 \%$

Dimana: $\mathrm{K}$ = Persentase ketuntasan belajar per siswa

Ketuntasan klasikal $=\frac{\text { jumlah siswa yang tuntas }}{\text { jumlah siswasatukelas }} \times 100 \%$

Siswa dikatakan tuntas belajarnya jika mendapat nilai 70 (tujuh puluh) atau lebih dan ketuntasan klasikal yang ditetapkan, yaitu $75 \%$.

Prosedur Penelitian

Penelitian Tindakan Kelas (PTK) terdiri dari dua siklus. Pelaksanaan pembelajaran pada siklus I dilakukan dalam tiga kali pertemuan. Masing-masing pertemuan pembelajaran dilaksanakan selama dua jam pelajaran atau 2 x 40 menit. Materi yang dipelajari pada pertemuan I adalah sifat cahaya dan cermin datar. Siklus II terdiri atas tiga pertemuan masing-masing pertemuan dengan durasi waktu 2 x 40 menit.

Observasi awal

Observasi awal dilakukan dengan: a) wawancara dengan wakil kepala sekolah urusan kurikulum dan observer, b) menentukan kelas yang digunakan penelitian, c) menetapkan fokus observasi dan d) menetapkan banyaknya siklus.

Siklus 1

Perencanaan Tindakan meliputi: 1) menyusun jadwal penelitian, 2) menyusun rencana pembelajaran dengan materi sifat-sifat cahaya, cermin datar, cermin cekung, dan cermin cembung, 3) menyusun LKPD, 4) menyusun soal tes prestasi belajar tiap siklus, 5) merancang pembagian kelompok siswa berdasarkan kelompok kooperatif, dan 6) menyiapkan lembar observasi .

Pelaksanaan tindakan kegiatan pembelajaran atau kegiatan inti dimulai pada tahap ini dengan melakukan pembelajaran sebagai pelaksanaan penelitian tindakan kelas. Kegiatan ini mengacu pada skenario pembelajaran menggunakan model STAD, yaitu: 1) menyajikan materi, 2) diskusi kelompok, 3) diskusi kelas, 4) kuis, dan 5) memberikan penghargaan.

Observer melakukan pengamatan menggunakan pedoman observasi yang telah direncanakan. Lembar observasi diamati oleh peneliti beserta observer terdiri dari:

\section{Frekuensi pertanyaan yang diajukan siswa}

Bertanya lebih dari dua kali

Bertanya dua kali

Bertanya sekali

Tidak bertanya sama sekali

\section{Perhatian}

Perhatian selalu fokus pada kegiatan yang harus dilaksanakan

Perhatian tidak selalu fokus pada kegiatan yang harus dilakukan

Perhatian terbagi dengan kegiatan lain yang tidak terkait dengan kegiatan pokok

Perhatian tidak fokus pada kegiatan yang harus dilakukan 


\section{Kerjasama antar siswa dalam menyelesaikan tugas}

Aktif mencari data dan mencari pasangan

Aktif mencari data dan tidak aktif mencari pasangan

Aktif mencari pasangan tidak aktif mencari data

Tidak aktif mencari data dan tidak aktif mencari pasangan

\section{Peningkatan sumber belajar yang dimanfaatkan oleh siswa}

Menggunakan lebih dri dua sumber belajar

Menggunakan 2 sumber belajar

Memiliki 1 sumber belajar

Tidak punya sumber belajar

Data yang diperoleh dari hasil observasi selama proses pembelajaran dilakukan analisis dengan rumus yang telah ditentukan, kemudian dilakukan refleksi sebagai bahan penyusunan rencana tindakan pada siklus berikutnya. Pada tahap refleksi, ada beberapa kriteria yang dijadikan sebagai rambu-rambu keberhasilan, misalnya: apakah proses pembelajaran sudah sesuai dengan rencana dan bagaimana peningkatan motivasi dan prestasi belajar siswa setelah penerapan model pembelajaran STAD di kelas 8 I SMPN 1 Dolopo Madiun semester genap Tahun Pelajaran 2014/2015.

Siklus II

Perencanaan Tindakan meliputi: (1) merencanakan tindakan berdasarkan hasil refleksi siklus I, (2) merencanakan observasi atau monitoring, (3) merencanakan refleksi, analisis, dan kesimpulan.

Pelaksanaan tindakan kegiatan yang mengacu pada skenario pembelajaran menggunakan model STAD, yaitu: (1) menyajikan materi, (2) diskusi kelompok, (3) diskusi kelas, (4) kuis, dan (5) memberikan penghargaan.

Kegiatan observasi dengan menggunakan pedoman observasi yang telah direncanakan, observer melakukan pengamatan: (1) apakah rencana yang telah ditetapkan dilaksanakan atau tidak, (2) apakah pelaksanaannya sesuai dengan rencana yang dibuat, (3) apakah pelaksanaannya itu berdampak pada motivasi siswa dan prestasi belajar siswa.

Data yang diperoleh dari hasil observasi selama proses pembelajaran dilakukan analisa dan dilakukan refleksi. Pada tahap refleksi ada kriteria yang dijadikan sebagai rambu-rambu keberhasilan yaitu apakah ada peningkatan terhadap motivasi dan prestasi belajar siswa kelas 8I di SMPN 1 Dolopo Madiun semester genap tahun pelajaran 2014/2015.

\section{Indikator Keberhasilan Tindakan}

Penelitian ini dikatakan berhasil apabila rata-rata motivasi belajar siswa siklus II lebih besar dari siklus I, dan apabila presentase ketuntasan klasikal siklus II dapat mencapai $85 \% 75 \%$.

\section{HASIL DAN PEMBAHASAN}

\section{Pelaksanaan Model Pembelajaran STAD}

Kegiatan pembelajaran siklus I berlangsung sesuai rencana. Pada siklus I, siswa masih beradaptasi dengan model pembelajaran yang baru pertama kali mereka kenal. Siswa masih agak canggung dengan batasan-batasan waktu yang disediakan di tiap tahap STAD. Pada tahap penyajian materi yang diisi dengan demonstrasi, sebagian siswa belum tertarik, sebagian maju ke depan untuk melihat dari dekat, tetapi masih ada yang duduk di belakang. Pada tahap diskusi kelompok, siswa yang sudah mengerti belum bisa menjelaskan kepada siswa yang belum mengerti dalam satu kelompoknya secara optimal. Dalam mengerjakan tugas kelompok, sebagian masih sendiri-sendiri sehingga kurang kerjasama dalam penyelesaian tugas. Pada tahap diskusi kelas, kelompok masih malu-malu untuk maju ke depan, akhirnya harus ditunjuk oleh guru. Pada tahap kuis, siswa belum terbiasa dengan soal-soal yang harus dikerjakan secara mandiri, masih ada siswa yang kerjasama, meskipun telah diingatkan, ini terjadi karena siswa belum menguasai materi pelajaran. 
Pada siklus I, siswa merasa waktu untuk diskusi kelompok kurang sehingga hasil diskusi belum optimal. Ada beberapa catatan penting selama siklus I sebagai berikut: (a) Sebagian besar siswa belum memahami fungsi dan perannya dalam kegiatan kelompok, akibatnya tugas kelompok dikerjakan sendiri-sendiri oleh setiap anggota kelompok tanpa adanya interaksi satu dengan yang lain. Penyebab dari masalah ini karena siswa belum terbiasa dengan model pembelajaran STAD. Oleh karena itu, sosialisasi peran dan fungsi siswa dalam kegiatan kelompok ditegaskan kembali kepada siswa. (b) Adanya ketergantungan di antara anggota kelompok belum terjadi, akibatnya kebersamaan dalam kelompok belum nampak. Siswa yang sudah memahami materi belum mau menjelaskan kepada teman satu kelompoknya yang belum memahami materi. Penyebab dari masalah ini adalah kesadaran dan kepedulian siswa yang sudah mengerti pada suatu materi ketika diskusi kelompok untuk bersedia menjelaskan kepada temannya yang belum mengerti pada materi tesebut. Demikian juga siswa yang belum mengerti pada materi diskusi kelompok, belum tampak memulai bertanya kepada siswa yang sudah mengerti. Sehingga saling ketergantungan belum terjadi. (c) Penegasan pemberian penghargaan pada waktu kegiatan pembelajaran terhadap anggota kelompok yang bekerjasama dengan kelompoknya, agar bisa menyelesaikan tugas tepat waktu. Penyebab dari masalah ini, karena penghargaan diberikan pada akhir pertemuan sehingga selama proses pembelajaran siswa tidak merasa ada dorongan untuk bekerjasama.

Kekurangan ini diperbaiki pada siklus II. Waktu diskusi kelompok yang semula dua puluh lima menit ditambah menjadi tiga puluh menit. Penambahan waktu diskusi kelompok dimanfaatkan oleh siswa yang belum mengerti untuk dapat bertanya kepada siswa yang sudah mengerti dengan waktu yang banyak.

Proses pembelajaran pada siklus II berjalan sesuai dengan rencana. Kegiatan pembelajaran berlangsung lancar. Siswa sudah memahami tahap-tahap model pembelajaran STAD. Siswa sudah memahami tahapan-tahapan yang akan mereka lakukan. Pada tahap penyajian materi yang diisi dengan demonstrasi, siswa antusias maju ke depan dan membantu guru. Pada tahap diskusi kelompok, siswa yang sudah mengerti pada materi diskusi menjelaskan kepada teman satu kelompoknya yang belum mengerti pada materi tersebut sampai bisa. Pada tahap diskusi kelas, kelompok maju ke depan tanpa malu-malu dan tidak di tunjuk guru.

Keterlaksanaan pembelajaran siklus II lebih lancar daripada siklus I. Proses pembelajaran pada siklus II memberikan hasil motivasi dan prestasi yang lebih baik. Karena siswa lebih antusias dengan model pembelajaran yang melibatkan mereka secara langsung.

\section{Motivasi Belajar}

Motivasi siswa diamati oleh tiga observer dengan menggunakan lembar observasi. Aspek motivasi yang diamati yaitu frekuensi pertanyaan yang diajukan siswa, perhatian siswa, kerjasama siswa dalam menyelesaikan tugas kelompok, dan peningkatan sumber belajar yang dimanfaatkan oleh siswa. Hasil observasi sebagai berikut:

\section{Tabel 1}

Hasil Motivasi Siswa Pada Siklus I dan Siklus II

\begin{tabular}{lllllllll}
\hline & \multicolumn{3}{c}{ SIKLUS I } & \multicolumn{5}{c}{ SIKLUS II } \\
\hline Aspek Motivasi & $\begin{array}{l}\text { Pert I } \\
(\%)\end{array}$ & $\begin{array}{l}\text { Pert II } \\
(\%)\end{array}$ & $\begin{array}{l}\text { Pert III } \\
(\%)\end{array}$ & $\begin{array}{l}\text { Rata-Rata } \\
(\%)\end{array}$ & $\begin{array}{l}\text { Pert I } \\
(\%)\end{array}$ & $\begin{array}{l}\text { Pert II } \\
(\%)\end{array}$ & $\begin{array}{l}\text { Pert III } \\
(\%)\end{array}$ & $\begin{array}{l}\text { Rata-Rata } \\
(\%)\end{array}$ \\
\hline $\begin{array}{l}\text { Frekuensi pertanyaan } \\
\text { yang diajukan siswa }\end{array}$ & 44,38 & 45,63 & 48,75 & 46,25 & 53,13 & 55,63 & 58,75 & 55,84 \\
Perhatian siswa & 74,38 & 78,13 & 79,38 & 77,30 & $\begin{array}{l}81,8 \\
8\end{array}$ & 86,25 & 88,13 & 85,42 \\
\hline $\begin{array}{l}\text { Kerjasama siswa dalam } \\
\text { kelompok }\end{array}$ & 53,75 & 58,13 & 58,75 & 56,88 & $\begin{array}{l}77,5 \\
0\end{array}$ & 81,25 & 84,38 & 81,04 \\
\hline $\begin{array}{l}\text { Peningkatan sumber } \\
\text { belajar yang } \\
\text { dimanfaatkan siswa }\end{array}$ & 51,25 & 52,50 & 53,13 & 52,29 & $\begin{array}{l}53,7 \\
5\end{array}$ & 56,25 & 58,12 & 56,04 \\
\hline Rata-rata Motivasi belajar siklus I & & & & & & & \\
\hline
\end{tabular}


Berdasarkan tabel di atas dapat diketahui bahwa motivasi belajar siswa yang terdiri atas: frekuensi pertanyaan yang diajukan siswa, perhatian siswa, kerjasama siswa dalam kelompok, dan peningkatan sumber belajar yang dimanfaatkan siswa pada siklus I mempunyai rata-rata 58,18\%, sedangkan pada siklus II rata-ratanya mencapai $69,59 \%$. Dari hasil tersebut dapat diketahui bahwa motivasi siswa meningkat $11,41 \%$. Peningkatan motivasi belajar siswa siklus II lebih besar dari siklus I, hal ini dapat dikatakan bahwa indikator peningkatan motivasi belajar siswa sudah tercapai. Adanya peningkatan motivasi siswa untuk belajar dikarenakan penerapan pembelajaran STAD, hal ini sesuai dengan hasil penelitian yang dilakukan Yudiasa dkk (2016) yang menyatakan bahwa penggunaan model STAD dapat meningkatkan motivasi belajar siswa. Dengan demikian, tujuan penelitian sudah tercapai dengan menggunakan metode pembelajaran STAD.

Peningkatan motivasi dari siklus I ke siklus II terjadi sesuai dengan tahap-tahap pada proses pembelajarannya. Siswa perhatian pada saat guru melakukan demonstrasi, bekerjasama dalam mengerjakan tugas kelompok, bertanya ketika diskusi kelompok dan diskusi kelas, serta memanfaatkan sumber belajar. Sehingga setiap tahap meningkatkan motivasi belajar siswa. Hal ini sesuai dengan penelitian yang dilakukan oleh Supriyo (2008) dan Rely (2008) bahwa model pembelajaran kooperatif STAD mampu meningkatkan motivasi belajar siswa.

\section{Prestasi Belajar}

Penerapan model pembelajaran STAD dilaksanakan untuk meningkatkan prestasi belajar siswa. Prestasi belajar yang dimaksud adalah tingkat kemampuan belajar fisika yang tercermin pada skor atau nilai kemampuan mengerjakan soal-soal fisika pada materi cermin dan lensa yang telah dibelajarkan. Soal yang digunakan untuk mengukur prestasi belajar adalah soal post test pada akhir siklus belajar. Data rata-rata tiap siklus prestasi belajar ada pada tabel 4 di bawah ini.

\section{Tabel 2}

Prestasi Belajar Siswa Siklus I

\begin{tabular}{llll}
\hline Interval & Titik tengah & Frekuensi Hasil Tes & \\
\hline $31-40$ & 35,5 & - & \\
$41-50$ & 45,5 & 4 & \\
$51-60$ & 55,5 & 5 & \\
$61-70$ & 65,5 & 6 & \\
$71-80$ & 75,5 & 8 & 27 \\
$81-90$ & 85,5 & 4 & \\
\hline Jumlah & & & \\
\hline
\end{tabular}

\section{Tabel 3}

Prestasi Belajar Siswa Siklus II

\begin{tabular}{llll}
\hline Interval & Titik tengah & Frekuensi Hasil Tes & \\
\hline $41-50$ & 45,5 & - & \\
$51-60$ & 55,5 & 3 & \\
$61-70$ & 65,5 & 5 & \\
$71-80$ & 75,5 & 13 & 27 \\
$81-90$ & 85,5 & 5 & \\
$91-100$ & 95,5 & 1 & \\
\hline \multicolumn{7}{c}{} \\
\hline
\end{tabular}




\section{Tabel 4}

Prestasi Belajar Siswa (Ketuntasan Klasikal)

\begin{tabular}{lll}
\hline Uraian & Tes Siklus I & Tes Siklus II \\
\hline Jumlah Siswa & 27 & 27 \\
Jumlah Siswa yang Tidak Tuntas Belajar & 9 & 3 \\
Siswa yang Tuntas Belajar & 18 & 24 \\
\% Ketuntasan Klasikal & $66,67 \%$ & $88,89 \%$ \\
\hline \multicolumn{2}{c}{ Kenaikan Persentase Ketuntasan Klasikal } & $22,22 \%$ \\
\hline
\end{tabular}

Dari tabel 4 di atas terlihat bahwa terjadi kenaikan ketuntasan klasikal yang menunjukkan kenaikan prestasi belajar pada siklus I dan siklus II sebesar 22,22\%. Siklus II rata-rata prestasi belajar lebih baik dari siklus I. Hal ini karena siswa telah mengikuti model pembelajaran STAD mulai dari tahap penyajian materi yang diisi dengan demonstrasi, siswa terlibat aktif membantu guru. Hasil penelitian ini sejalan dengan Purwanti dan Gafur (2018) bahwasanya penerapan model STAD dapat meningkatkan hasil belajar sekaligus motivasi siswa. Sholeh (2017) juga menyatakan bahwa STAD dapat meningkatkan motivasi belajar siswa baik secara kelompok maupun individu sehingga hal tersebut dapat memberikan pengaruh positif terhadap hasil atau prestasi belajar siswa. Pada tahap diskusi kelompok, siswa yang belum mengerti pada materi yang sedang didiskusikan oleh kelompok tersebut bertanya kepada teman dalam kelompoknya yang sudah mengerti pada materi tersebut sampai bisa. Pada tahap diskusi kelas, siswa bertukar pikiran lebih mendalam mengenai tugas kelompok yang dikerjakan, sehingga siswa aktif dan memiliki pengalaman belajar. Perubahan tingkah laku pada penerapan model pembelajaran STAD berasal dari interaksi sosial, dimana siswa bertanggung jawab terhadap diri sendiri dan anggota kelompoknya. Prestasi belajar merupakan suatu puncak proses belajar yang dipengaruhi oleh proses-proses penerimaan, keaktifan, penyimpanan, serta pemanggilan untuk pembangkit pesan dan pengalaman (Dimyati \& Mudjiono, 2006).

\section{KESIMPULAN}

Kegiatan Penelitian Tindakan Kelas (PTK) telah dilaksanakan dan diuraikan di pembahasan penelitian dengan hasil telah memenuhi indikator penelitian yang berarti bahwa tujuan penelitian telah tercapai. Sehingga dapat disimpulkan, bahwa Model Pembelajaran STAD dapat meningkatkan motivasi dan prestasi belajar siswa kelas 8 I SMPN 1 Dolopo Madiun semester genap tahun pelajaran 2014/2015.

\section{DAFTAR PUSTAKA}

Aufa, M., \& Haq, A. L. M. (2020). Pengaruh Model Student Teams Achievement Division (STAD) Terhadap Prestasi Belajar Siswa. Edukasi, 12(2). 77-84.

Dewi. (2007). Pengembangan Model Pembelajaran Kooperatif Tipe STAD terhadapPrestasi Belajar Siswa pada Pembelajaran Fisika. Skripsi tidak diterbitkan. Bandung: Universitas Pendidikan Indonesia.

Dimyati., \& Mujiono. (2006). Belajar dan pembelajaran. Jakarta: Rineka Cipta.

Ellyana. (2007). Penerapan Pembelajaran Kooperatif Model STAD untuk Meningkatkan Motivasi, Aktivitas dan Hasil Belajar Biologi Siswa Kelas VII-A SMP PGRI Purwodadi Kabupaten Pasuruan. Skripsi tidak diterbitkan. Malang: Universitas Negeri Malang.

Hamalik, O. (2001). Proses Belajar mengajar. Jakarta: Bumi Aksara.

Hamzah, B. U. (2008). Teori Motivasi dan Pengukurannya. Jakarta: Bumi Aksara. 
Hirmanudin. (2015). Penerapan Metode Kooperatif Tipe STAD untuk Meningkatkan Hasil Belajar Siswa di SD Negeri 3 Simeulue Barat. Jurnal Mudarrisuna, 4(2). 689-704.

Moleong, L.J. (2005). Metodelogi Penelitian Kualitatif. Bandung: Remaja Rosdakarya.

Purwanti, S., \& Gafur, A. (2018). Penerapan pembelajaran kooperatif tipe STAD untuk meningkatkan motivasi dan hasil belajar PKn. SOCIA: Jurnal Ilmu-Ilmu Sosial, 15(2). 140-148.

Ridwan. (2008). Ketercapaian Prestasi Belajar. http://ridwan202.wordpress.com. Diakses 25 Juli 2009.

Sholeh, A. F. (2017). Penerapan Pembelajaran Kooperatif Tipe Stad Untuk Meningkatkan Motivasi Belajar Siswa. Jurnal Pi, Pend. Mat. STKIPH, 1(1). 1-5

Slameto. (2003). Belajar dan Faktor-faktor yang Mempengaruhinya. Jakarta: Rineka Cipta.

Soeharto. (2003). Teknologi Pembelajaran. Surabaya: Surabaya Intellectual Cub.

Suciati, (2001). Teori Belajar dan Motivasi. Jakarta: Pusat antar Universitas untuk Peningkatan dan Pengembangan Aktivitas Instruksional Dirjen Dikti Depdiknas.

Sujana, N. (2008). Penilaian Hasil Proses Belajar Mengajar. Bandung: PT Remaja Rosda karya.

Sumarni, E.T., \& Mansurdin. (2020). Model Kooperative Learning Tipe STAD pada Motivasi Belajar Siswa di Sekolah Dasar. Jurnal Pendidikan Tambusai, 4(2). 1309-1319.

Supriyo. (2008). Penerapan Model Pembelajaran Kooperatif STAD (Student Teams Achievement Divisions) untuk Meningkatkan Motivasi Belajar Fisika Siswa Kelas IX-D SMPN 5 Malang. PTK Tidak diterbitkan Malang.

Susilo, H. (2007). Penelitian Tindakan Kelas Sebagai Sarana Pengembangan Keprofesionalan Guru dan Calon Guru. Malang: Bayumedia.

Wongkeban. (2008). Hubungan Motivasi Belajar dengan Prestasi Belajar. http://www.pdf-searchengine.com/motivasi-belajar-pdf.htm, Diakses tanggal 5 Januari 2009.

Yudiasa, I. K., Dibia, I. K., \& Sumantri, M. (2016). Penerapan Model Pembelajaran Stad Untuk Meningkatkan Motivasi Dan Hasil Belajar IPA Kelas V. Mimbar PGSD, 5(3). 1-11. 